\title{
BMJ
}

\section{Relation of iron and red meat intake to blood pressure: cross sectional epidemiological study}

\begin{abstract}
Ioanna Tzoulaki, lecturer in epidemiology, ${ }^{1}$ Ian J Brown, research assistant, ${ }^{1}$ Queenie Chan, senior research officer, ${ }^{1}$ Linda Van Horn, professor of preventive medicine, ${ }^{2}$ Hirotsugu Ueshima, professor of medicine, ${ }^{3}$ Liancheng Zhao, professor of epidemiology, ${ }^{4}$ Jeremiah Stamler, professor emeritus, ${ }^{2}$ Paul Elliott, professor, ${ }^{1}$ for the International Collaborative Research Group on Macro-/Micronutrients and Blood Pressure
\end{abstract}

Department of Epidemiology and Public Health, Imperial College London, St Mary's Campus, London W2 1 PG

${ }^{2}$ Feinberg School of Medicine, Northwestern University, Chicago, IL, USA

${ }^{3}$ Department of Health Science, Shiga University of Medical Science, Shiga, Japan

${ }^{4}$ Cardiovascular Institute, Fu Wai Hospital, Chinese Academy of Medical Sciences and Peking Union Medical College, Beijing, China

Correspondence to: I Tzoulaki I.Tzoulaki@imperial.ac.uk

\section{ABSTRACT}

Objective To investigate associations of dietary iron (total, haem, and non-haem), supplemental iron, and red meat with blood pressure.

Design Cross sectional epidemiological study.

Setting 17 population samples from Japan, China, the United Kingdom, and the United States participating in the international collaborative study on macro-/

micronutrients and blood pressure (INTERMAP).

Participants 4680 adults aged 40-59.

Main outcome measure Average of eight blood pressure readings.

Results In multiple linear regression analyses dietary total iron and non-haem iron were consistently inversely associated with blood pressure. With adjustment for potential non-dietary and dietary confounders, dietary total iron intake higher by $4.20 \mathrm{mg} / 4.2 \mathrm{MJ}$ (2 SD) was associated with $-1.39 \mathrm{~mm} \mathrm{Hg}(\mathrm{P}<0.01)$ lower systolic blood pressure. Dietary non-haem iron intake higher by $4.13 \mathrm{mg} / 4.2 \mathrm{MJ}$ (2 SD) was associated with $-1.45 \mathrm{~mm} \mathrm{Hg}$ ( $P<0.001)$ lower systolic blood pressure. Differences were smaller for diastolic blood pressure. In most models haem iron intake from food was positively, non-significantly associated with blood pressure. Iron intake from combined diet and supplements yielded smaller associations than dietary iron alone. Red meat intake was directly associated with blood pressure; $102.6 \mathrm{~g} / 24 \mathrm{~h}$ (2 $\mathrm{SD}$ ) higher intake was associated with $1.25 \mathrm{~mm} \mathrm{Hg}$ higher systolic blood pressure. Associations between red meat and blood pressure persisted after adjustment for multiple confounders.

Conclusion Non-haem iron has a possible role in the prevention and control of adverse blood pressure levels. An unfavourable effect of red meat on blood pressure was observed. These results need confirmation including in prospective studies, clinical trials, and from experimental evidence on possible mechanisms.

\section{INTRODUCTION}

Despite progress in the detection and treatment of hypertension in recent years, high blood pressure is epidemic and remains a major cause of cardiovascular morbidity and mortality worldwide. ${ }^{1-3}$ Multifactorial influences of diet on blood pressure include sodium intake, alcohol intake, caloric imbalance (direct), potassium intake (inverse), and possible favourable effects of minerals, vegetable protein, and omega-3 polyunsaturated fatty acids. ${ }^{4-11}$

In 1981 the "iron-heart" hypothesis was proposed to explain differences in rates of coronary heart disease between men and premenopausal women on the basis of differences in their iron stores. ${ }^{12}$ Premenopausal women were thought to lose important amounts of iron storage through menstruation. Since this initial report, several epidemiological studies and a meta-analysis have examined the role of various measures of iron in coronary heart disease and diabetes, with conflicting conclusions. ${ }^{12-20}$ Some studies have shown an increased risk of coronary heart disease with greater haem iron intake (originating mainly from animal sources) but not with total iron intake. ${ }^{1421}$ The effect of non-haem iron (all other sources of iron) has not been explored, neither has consumption of iron from dietary supplements or fortified foods. Haem and non-haem iron have distinct metabolic pathways and their intestinal absorption is influenced by different nutrients, therefore they could have distinct roles in the pathophysiology of cardiovascular disease. ${ }^{22} 23$

The relation between iron and blood pressure is largely unknown. Iron is a redox active transition metal that might contribute to the production of reactive oxygen species, oxidative stress, and inflammationall possibly adversely related to blood pressure levels. ${ }^{2425}$ We investigated associations of dietary iron intake (total, haem, and non-haem); one major food source of haem iron, red meat; and food plus supplemental iron, with blood pressure in the cross sectional population based international collaborative study on macro-/micronutrients and blood pressure (INTERMAP).

\section{METHODS}

The methods used by the international collaborative of macronutrients and blood pressure have been 
described in detail. ${ }^{26}$ Briefly, the study population (1996-9) comprises 2359 men and 2321 women aged 40-59 from 17 samples: Japan (four samples), the People's Republic of China $(\mathrm{n}=3)$, the United Kingdom $(\mathrm{n}=2)$, and the United States $(\mathrm{n}=8)$. Data were collected cross sectionally. Each sample was representative of a defined target population; samples were included from both the community and the workforce. People were selected randomly from population lists, stratified by age and sex to give about equal numbers ( 65 people) in each of four 10 year age and sex groups. ${ }^{26}$ The mean participation rate was $49 \%$. Each participant attended the research clinic on four occasions: two visits on consecutive days, a gap averaging three weeks, then two further consecutive visits.

Blood pressure was measured twice at each clinic visit with a random zero sphygmomanometer. Measurements were taken with the participant seated, after a rest of at least five minutes and with the bladder emptied. Korotkoff sounds I and V were used for systolic and diastolic blood pressures. At two visits height and weight were measured and questionnaire data were obtained on daily alcohol intake over the past seven days and on possible confounders.

At each visit a trained interviewer used the in-depth multipass 24 hour recall method to collect data on diet. This method uses open ended questions, is suited to multiple ethnicities and languages, does not require participants to be literate, and is designed to capture total dietary intake (macronutrients and micronutrients) for 24 hours. ${ }^{27}$ We therefore recorded all foods and drinks, including supplements, consumed in the previous 24 hours. Quality control measures were extensive. ${ }^{28}$ Participants gave written informed consent on their first clinic visit, before data collection.

We carried out two timed 24 hour urine collections, coinciding with the two pairs of consecutive clinic visits. Measurements taken at a central laboratory included sodium, potassium, and creatinine levels. To estimate technical error we split about $8 \%$ of local specimens before shipment to the central laboratory. ${ }^{26}$

We excluded those who did not attend all four clinic visits, those with dietary data considered unreliable, those whose energy intake from any 24 hour recall was less than 2.1 MJ or more than $21 \mathrm{MJ}$ (women), or $33 \mathrm{MJ}$ (men), those with two unavailable urine collections, and those whose data on other variables were incomplete or indicated violation of the protocol. Overall, we excluded 215 people. For each participant excluded we recruited another participant.

\section{Statistical analysis}

To provide comparable data on 83 nutrients across the four countries, including iron, we converted data on food and dietary supplements into nutrient intakes by using country specific food tables, updated and standardised by the Nutrition Coordinating Centre, University of Minnesota. ${ }^{29}$ We calculated nutrient intakes from only foods and from foods plus dietary supplements. For nutrients supplying energy we calculated intake as percentage millijoules and for others as intake per $4.2 \mathrm{MJ}$. We also calculated nutrients as amount per 24 hours. To estimate intake of haem and non-haem iron from dietary total iron intake we used an established formula ${ }^{30}$ taking into account the source of iron (meat, poultry, fish $v$ other). We used the data on food to characterise the main food groups supplying iron and to estimate each participant's red meat intake (defined as skeletal muscle tissue of all mammals) and their consumption of beef. Measurements for each participant were averaged for blood pressure and nutrient variables across the four visits, and for urinary excretions across the two 24 hour collections.

From the mean of the four visits we estimated the reliability of iron and red meat intake for individual participants using the formula $1 /[1+($ ratio/4) $] \times 100$, where the ratio is the variance within a participant divided by the variance between participants, calculated separately for eight sex and country strata and pooled by weighting of each stratum specific estimate by $n-1$. This gives an estimate of the size of an observed regression coefficient as a percentage of the theoretical coefficient in a univariate regression analysis of blood pressure on iron, red meat, or beef. ${ }^{3132}$

We used partial correlation to explore the associations among dietary variables, adjusted for sample, age, and sex, and pooled across countries and weighted by sample size. To examine the relations of iron intake (total, haem, non-haem, total plus supplements, all as $\mathrm{mg} / 4.2 \mathrm{MJ}$ ) and intake of red meat or beef (grams over 24 hours, adjusted for energy intake) to systolic and diastolic blood pressure we used multiple linear regression analyses. Adjustment for possible confounders was done sequentially: for sample, age, sex, weight, height, reported special diet, use of dietary supplements, moderate or heavy physical activity (hours daily), doctor diagnosed cardiovascular disease and diabetes, and family history of hypertension (model 1); plus 24 hour urinary excretion of sodium and potassium (or urinary sodium or creatinine, potassium to creatinine ratios) and alcohol intake over 14 days (model 2); plus levels of dietary cholesterol, saturated fatty acids, and polyunsaturated fatty acids (model 3); plus intake of either animal protein, vegetable protein, dietary fibre, magnesium, phosphorus, calcium, haem iron (red meat analysis only) or non-haem iron (red meat analysis only) entered separately to avoid colinearity (models $4 \mathrm{a}-\mathrm{h}$ ).

To estimate the overall association we fitted regression models by country and coefficients pooled across countries, weighted by the inverse of variance. We tested heterogeneity across countries and we assessed interactions for age and sex. Because vitamin $\mathrm{C}$ and alcohol increase the intestinal absorption of non-haem iron we tested interactions with these two variables in models examining non-haem iron. ${ }^{2223}$

We carried out regression analyses on four cohorts: all 4680 participants; 2238 "non-intervened" participants (not receiving a special diet; not consuming dietary supplements; no diagnosed cardiovascular disease and diabetes; not taking drugs for high blood 
pressure, cardiovascular disease, or diabetes - that is, exclusion of people whose characteristics might bias the relations between iron and blood pressure ${ }^{1011}$ ); 3671 non-hypertensive participants (systolic blood pressure $<140 \mathrm{~mm} \mathrm{Hg}$, diastolic blood pressure $<90 \mathrm{~mm} \mathrm{Hg}$, not taking antihypertensive drugs); and 2038 "non-intervened" non-hypertensive participants.

Sensitivity analyses concerned the analysis of iron from food plus dietary supplements (with and without exclusion of 15 men and 44 women with a supplemental iron intake $>30 \mathrm{mg} /$ day, indicative of chronic iron deficiency); adjustment for total carbohydrate, starch, or total sugars (percentage millijoules); use of nutrient densities of iron (haem, non-haem, and total) adjusted for energy; use of amount per 24 hours of iron intakes (haem, non-haem, and total) adjusted for energy; and exclusion of people (predefined) with noticeable variability in nutrient intake or blood pressure. For ease of interpretation we transformed regression coefficients to represent difference in blood pressure for each two standard deviation higher intake of iron (haem, non-haem, or total), red meat, or beef. We adjusted each standard deviation for country, estimated by the mean square error from country adjusted analysis of variance.

Analyses (IT, IJB) were done with SAS version 9.1. We considered a $\mathrm{P}$ value $<0.01$ to be significant. A P value $<0.05$ was used for interaction terms and tests for heterogeneity across countries.

\section{RESULTS}

Mean systolic blood pressure ranged from $117.2 \mathrm{~mm}$ $\mathrm{Hg}$ in Japan to $121.3 \mathrm{~mm} \mathrm{Hg}$ in China. Mean diastolic blood pressure ranged from $73.2 \mathrm{~mm} \mathrm{Hg}$ in China to $77.3 \mathrm{~mm} \mathrm{Hg}$ in the United Kingdom. Mean iron consumption was higher in the United States and China (7.8 mg/4.2 MJ for both) than in the United Kingdom and Japan (6.2 mg/4.2 MJ and $5.3 \mathrm{mg} / 4.2$ $\mathrm{MJ})$. Mean body mass index and energy intake were lower in Japan and China and highest in the United States. (See table 1 on bmj.com for descriptive data of each country.)
About $6 \%$ of iron intake in Western countries (United Kingdom and United States) was the haem component. In Japan and China $9 \%$ and $3 \%$ of iron intake was haem iron, with the main food source being fish (Japan 61\%, China 88\%). In the United Kingdom and United States meat supplied $90 \%$ and $87 \%$ of haem iron, respectively (table 1). The main food sources of non-haem iron in Japan and China were vegetables and beans and in the United Kingdom and United States bread and cereals.

Univariate estimates of intra-individual reliability on the basis of four 24 hour recalls for each of the 4680 participants were: for total iron, observed regression coefficient $55.8 \%$ of theoretical coefficient; for haem iron, 39.8\%; for non-haem iron, $59.7 \%$ (all mg/4.2 MJ); for red meat, $44.0 \%(\mathrm{~g} / 24 \mathrm{~h})$. This means, theoretically, that true associations might be larger than the observed associations-for example $1.7(1 / 0.597)$ times larger for non-haem iron.

\section{Partial correlation data}

Haem iron intake from food was positively correlated with intake of total protein $(\mathrm{r}=0.53)$ and animal protein $(\mathrm{r}=0.63)$. Non-haem iron intake was positively correlated with intake of dietary vegetable protein $(\mathrm{r}=0.47)$, fibre $(\mathrm{r}=0.54)$, phosphorus $(\mathrm{r}=0.47)$, calcium $(\mathrm{r}=0.42)$, and magnesium $(\mathrm{r}=0.59)$, and 24 hour urine potassium excretion $(\mathrm{r}=0.50)$.

Association of total, haem, and non-haem iron with blood pressure

Total iron intake from food was inversely related to systolic blood pressure (table 2). Inverse differences in diastolic blood pressure were smaller than those for systolic blood pressure. In model 3 (adjusted for multiple possible confounders including urinary sodium and potassium, alcohol intake, dietary cholesterol, saturated and polyunsaturated fatty acids) a $2 \mathrm{SD}$ higher total dietary iron intake $(4.2 \mathrm{mg} / 4.2 \mathrm{MJ})$ was associated with $1.39 \mathrm{~mm} \mathrm{Hg}$ lower systolic blood pressure $(\mathrm{P}<0.01)$ and with $0.68 \mathrm{~mm} \mathrm{Hg}$ lower diastolic blood pressure $(\mathrm{P}=0.01)$. Associations with systolic

\begin{tabular}{|c|c|c|c|c|c|c|c|c|}
\hline \multirow[b]{2}{*}{ Variables } & \multicolumn{2}{|c|}{ Japan } & \multicolumn{2}{|l|}{ China } & \multicolumn{2}{|c|}{ United Kingdom } & \multicolumn{2}{|c|}{ United States } \\
\hline & Food source & $\begin{array}{c}\% \text { of total } \\
\text { diet }\end{array}$ & Food source & $\begin{array}{c}\% \text { of total } \\
\text { diet }\end{array}$ & Food source & $\begin{array}{c}\% \text { of total } \\
\text { diet }\end{array}$ & Food source & $\begin{array}{c}\% \text { of total } \\
\text { diet }\end{array}$ \\
\hline \multicolumn{9}{|l|}{$\begin{array}{l}\text { Haem iron } \\
(\mathrm{mg} / 24 \mathrm{~h}) \text { : }\end{array}$} \\
\hline 1 & Fish & 61 & Fish & 88 & Meat & 90 & Meat & 87 \\
\hline 2 & Meat & 39 & Meat & 12 & Fish & 10 & Fish & 13 \\
\hline \multicolumn{9}{|c|}{$\begin{array}{l}\text { Non-haem iron } \\
(\mathrm{mg} / 24 \mathrm{~h}) \text { : }\end{array}$} \\
\hline 1 & Vegetables, beans & 27 & Vegetables, beans & 27 & Bread rolls, biscuits & 25 & Cereals & 16 \\
\hline 2 & $\begin{array}{l}\text { Vegetarian meat } \\
\text { substitutes }\end{array}$ & 13 & Grains, flour & 22 & Vegetables, beans & 18 & Bread rolls, biscuits & 15 \\
\hline 3 & Fish & 10 & Pasta, rice, noodles & 15 & Cereals & 15 & Vegetables, beans & 14 \\
\hline 4 & Pasta, rice, noodles & 8 & Condiments, seasonings & 5 & Meat & 9 & Grains, flour & 10 \\
\hline 5 & Eggs & 7 & $\begin{array}{l}\text { Cakes, puddings, cookies, } \\
\text { other sweet snacks }\end{array}$ & 5 & $\begin{array}{l}\text { Cakes, puddings, cookies, } \\
\text { other sweet snacks }\end{array}$ & 8 & Meat & 9 \\
\hline
\end{tabular}


Table 2 Estimated differences in systolic and diastolic blood pressure associated with dietary iron intake (mg/4.2 MJ) higher by $2 \mathrm{SD} \dagger(\mathrm{mg} / 4.2 \mathrm{MJ})$ in 4680 adults

Difference $(99 \% \mathrm{Cl})$ in

Model $\quad$ Systolic blood pressure $(\mathrm{mm} \mathrm{Hg}) \quad$ Diastolic blood pressure $(\mathrm{mm} \mathrm{Hg})$

Total dietary iron $(\mathrm{mg} / 4.2 \mathrm{M})$ :

\begin{tabular}{lll}
\hline 1 & $-2.06(-3.06 \text { to }-1.07)^{\star \star \star}$ & $-1.07(-1.75 \text { to }-0.39)^{\star \star \star}$ \\
\hline 2 & $-1.44(-2.46 \text { to }-0.43)^{\star \star \star}$ & $-0.71(-1.41 \text { to }-0.02)^{\star \star}$ \\
\hline 3 & $-1.39(-2.45 \text { to }-0.34)^{\star \star}$ & $-0.68(-1.37$ to 0.01$)$ \\
\hline $4 \mathrm{a}$ & $-1.40(-2.55 \text { to }-0.25)^{\star \star}$ & $-0.73(-1.51$ to 0.06$)$ \\
\hline $4 \mathrm{~b}$ & $-1.17(-2.32 \text { to }-0.02)^{\star \star}$ & $-0.47(-1.26$ to 0.32$)$ \\
\hline $4 \mathrm{~d}$ & $-1.10(-2.32$ to 0.12$)$ & $-0.61(-1.44$ to 0.22$)$ \\
\hline $4 \mathrm{e}$ & $-0.85(-2.01$ to 0.31$)$ & $-0.30(-1.10$ to 0.50$)$ \\
\hline $4 \mathrm{f}$ & $-1.06(-2.17$ to 0.05$)$ & $-0.43(-1.19$ to 0.33$)$ \\
\hline
\end{tabular}

Non-haem iron (mg/4.2 Ml):

\begin{tabular}{lll}
\hline 1 & $-2.17(-3.17 \text { to }-1.18)^{\star \star \star}$ & $-1.13(-1.81,-0.45)^{\star \star \star}$ \\
\hline 2 & $-1.51(-2.53 \text { to }-0.48)^{\star \star \star}$ & $-0.75(-1.45 \text { to }-0.05)^{\star \star}$ \\
\hline 3 & $-1.45(-2.51 \text { to }-0.38)^{\star \star \star}$ & $-0.73(-1.43 \text { to }-0.04)^{\star \star}$ \\
\hline 4a & $-1.48(-2.64 \text { to }-0.31)^{\star \star \star}$ & $-0.79(-1.58$ to 0.01$)$ \\
\hline 4b & $-1.22(-2.40 \text { to }-0.05)^{\star \star}$ & $-0.50(-1.31$ to 0.30$)$ \\
\hline 4c & $-1.16(-2.39$ to 0.07$)$ & $-0.67(-1.51$ to 0.17$)$ \\
\hline 4d & $-0.90(-2.07$ to 0.26$)$ & $-0.34(-1.14$ to 0.46$)$ \\
\hline 4e & $-1.08(-2.20$ to 0.04$)$ & $-0.45(-1.23$ to 0.32$)$ \\
\hline 4f & $-1.49(-2.56 \text { to }-0.42)^{\star \star \star}$ & $-0.72(-1.45$ to 0.01$)$
\end{tabular}

Haem iron (mg/4.2 M):

\begin{tabular}{lcl}
\hline 1 & $0.56(-0.52$ to 1.64$)$ & $0.27(-0.45$ to 0.98$)$ \\
\hline 2 & $0.19(-0.88$ to 1.27$)$ & 0.10 (-0.62 to 0.82$)$ \\
\hline 3 & $0.06(-1.08$ to 1.21$)$ & $0.14(-0.63$ to 0.90$)$ \\
\hline 4a & $0.03(-1.12$ to 1.18$)$ & $0.13(-0.63$ to 0.90$)$ \\
\hline 4b & $-0.11(-1.28$ to 1.05$)$ & $0.02(-0.75$ to 0.80$)$ \\
\hline 4c & $0.08(-1.07$ to 1.23$)$ & $0.15(-0.62$ to 0.92$)$ \\
\hline 4d & $0.19(-0.97$ to 1.36$)$ & $0.20(-0.57$ to 0.98$)$ \\
\hline 4e & $-0.19(-1.35$ to 0.97$)$ & $0.01(-0.77$ to 0.78$)$ \\
\hline 4f & $0.16(-1.23$ to 1.55$)$ & $0.18(-0.74$ to 1.10$)$ \\
\hline
\end{tabular}

1=age, sex, sample, height, weight, special diet, supplement use, physical activity, cardiovascular disease and diabetes, and family history of hypertension; $2=$ plus urinary sodium, urinary potassium, and alcohol; $3=$ plus cholesterol, saturated fatty acids, and polyunsaturated fatty acids; $4 \mathrm{a}=$ plus fibre; $4 \mathrm{~b}=0$ or plus vegetable protein; $4 \mathrm{C}=$ or plus magnesium, $4=$ or plus phosphorus; $4 \mathrm{e}=$ or plus calcium; $4 \mathrm{f}=$ or plus animal protein. $\star * \star P<0.001$.

**P<0.01.

†2 SD difference: $4.20 \mathrm{mg} / 4.2 \mathrm{MJ}$ (total dietary iron), $4.13 \mathrm{mg} / 4.2 \mathrm{MJ}$ (non-haem iron), and 0.61 (haem iron) $\mathrm{mg} / 4.2 \mathrm{MJ}$.

\section{Subcohort analyses}

Associations between iron intake and blood pressure in the subcohort of 2238 non-intervened participants were similar to the whole cohort (see table 2 on bmj.com). Estimated confidence intervals were wider, reflecting the small sample size. Associations of iron, non-haem iron, and haem iron intakes with blood pressure were similar after the exclusion of hypertensive participants from the entire cohort $(n=3671)$ and from the subcohort of 2038 non-intervened participants (see tables 3 and 4 on bmj.com).

\section{Red meat}

Red meat consumption varied across countries. Participants in China reported the lowest mean consumption $(24 \mathrm{~g} / 24 \mathrm{~h})$ and had the highest prevalence $(26 \%)$ of no red meat consumption on at least one of the four surveyed days. Mean red meat intake over 24 hours was $39 \mathrm{~g}$ in Japan, $91 \mathrm{~g}$ in the United Kingdom, and $76 \mathrm{~g}$ in the United States. Consumption of red meat was positively associated with systolic and diastolic blood pressures (table 3). No significant heterogeneity was observed across countries. In model 3 , higher red meat intake by $2 \mathrm{SD}(103 \mathrm{~g} / 24 \mathrm{~h})$ was associated with $1.25 \mathrm{~mm} \mathrm{Hg}$ higher systolic blood pressure $(\mathrm{P}<0.01)$ and $0.73 \mathrm{~mm} \mathrm{Hg}$ higher diastolic blood pressure $(\mathrm{P}=0.01)$. Associations between red meat and blood pressure were unaffected by controlling for haem iron or animal protein intake (models $4 \mathrm{~g}$ and $4 \mathrm{~h}$ ). Only $5 \%$ of red meat intake among participants from China was beef compared with 33\% in Japan, $40 \%$ in the United Kingdom, and 66\% in the United States. When beef was analysed separately, associations with blood pressure were positive but mostly smaller (table 3). For example, in model 3, higher beef intake by $2 \mathrm{SD}(75 \mathrm{~g} / 24 \mathrm{~h})$ was associated with $0.90 \mathrm{~mm} \mathrm{Hg}$ higher systolic blood pressure and $0.50 \mathrm{~mm} \mathrm{Hg}$ higher diastolic blood pressure. Associations between red meat or beef intake and blood pressure in previously described subcohorts-for example, in non-intervened participants $(\mathrm{n}=2238)$ were similar to the whole cohort.

\section{Sensitivity analyses}

After further adjustments for total carbohydrates, starch, or sugars, the associations between intake of iron (total, haem, or non-haem) or red meat or beef with blood pressure were of the same size and strength as those presented in tables 2 and 3. Participants from China did not consume any dietary supplements containing iron, except for two participants who took high doses of supplemental iron (>30 mg/24 h). Supplements containing iron were consumed by $5 \%$ of participants from Japan, 11\% from the United Kingdom, and 31\% from the United States. In the United States the average total iron intake increased from $7.8 \mathrm{mg} / 4.2 \mathrm{MJ}$ to $9.7 \mathrm{mg} / 4.2 \mathrm{MJ}$ when iron from supplements was included. In both Japan and the United Kingdom addition of supplementary iron resulted in only small increases in total iron intake (see table 1 on bmj.com). Total iron intake from diet 
and supplements combined was consistently inversely associated with systolic blood pressure and diastolic blood pressure; associations were weaker than those for dietary iron alone. For example, in model 3, after exclusion of 59 participants with a high (>30 mg) supplement intake, higher total iron intake by $2 \mathrm{SD}$ was associated with a difference in systolic blood pressure of $-0.33 \mathrm{~mm} \mathrm{Hg}$ (95\% confidence interval -1.10 to $0.44)$ and a difference in diastolic blood pressure of $-0.70 \mathrm{~mm} \mathrm{Hg}(-1.81$ to 0.41$)$. Inclusion of these participants further weakened the associations. In sensitivity analyses, red meat showed slightly stronger associations with blood pressure; associations for iron intake (total, haem, and non-haem) and blood pressure resulted in similar estimates as those in table 2.

\section{DISCUSSION}

Intake of total iron and non-haem iron are inversely related to blood pressure. Direct associations of haem iron with blood pressure were not statistically significant. Red meat consumption was positively associated with blood pressure.

Despite several studies on dietary iron and heart disease, ${ }^{13-16182021}$ the relation of a high iron diet to blood pressure is unknown. Iron is hypothesised to play a detrimental part in atherosclerotic disease through mechanisms of oxidative stress and inflammation. We, however, report an inverse relation between total dietary iron intake and blood pressure. When we separated total dietary iron into haem and non-haem components, we observed a differential effect of these two iron sources on blood pressure; non-haem iron was inversely associated with blood pressure whereas haem iron was mainly positively although not significantly associated with blood pressure.

Separating iron sources into the haem and non-haem components makes sense biologically because their mechanisms of absorption differ. The availability of non-haem iron is inhibited or enhanced by several dietary factors - for example, vitamin $\mathrm{C}$ and alcoholand its bioavailability varies significantly. ${ }^{33}$ Absorption of haem iron is more complete and less regulated than that of non-haem iron. ${ }^{33}$ About 25\% of haem iron compared with $2.5 \%$ of non-haem iron is absorbed in healthy people; haem iron, but not non-haem iron, correlates with serum ferittin, an indicator of total iron stores. ${ }^{34}$ Finally, gut absorption of non-haem iron is largely decreased in populations replete with iron whereas the absorption of haem iron is little affected. ${ }^{34}$

The inverse relation of non-haem iron to blood pressure, although consistent in all our multivariable analyses, may reflect correlations of non-haem iron with multiple other nutrients from vegetable foods, such as vegetable protein, phosphorus, magnesium, fibre, and calcium (correlation coefficients between 0.50 and 0.60 ). For example, the addition of phosphorus intake to the multivariable model reduced the size of association of non-haem iron with systolic blood pressure by $38 \%$. To the best of our knowledge, no previous data exist on non-haem iron and blood pressure, and therefore inferences about causality are premature; our results await confirmation in other population samples, clinical trials, and experimental studies that focus on the potential biological role of non-haem iron in the regulation of blood pressure. Also, the observed differences in blood pressure associated with higher non-haem iron intake were relatively small. Our study was, however, designed to investigate small but additive contributions of several nutrients on blood pressure. Such effects, although clinically small individually, have public health relevance for the general population where a mean reduction of only $2-3 \mathrm{~mm} \mathrm{Hg}$ systolic blood pressure could result in an important reduction in burden from cardiovascular disease. ${ }^{35}$

Haem iron showed direct weak associations with blood pressure. Haem iron is found mainly in red meat, poultry, and seafood; it is a major component of total iron intake in Western diets. Its association with blood pressure probably reflects the adverse relation of meat intake to blood pressure observed in the present and

Table 3 | Estimated differences in systolic and diastolic blood pressure associated with dietary red meat intake $(\mathrm{g} / 24 \mathrm{~h})$ higher by $2 \mathrm{SD}+(\mathrm{g} / 24 \mathrm{~h})$ in 4680 adults

\begin{tabular}{|c|c|c|}
\hline \multirow[b]{2}{*}{ Model } & \multicolumn{2}{|c|}{ Difference $(99 \% \mathrm{Cl})$} \\
\hline & $\begin{array}{c}\text { Systolic blood } \\
\text { pressure }(\mathrm{mm} \mathrm{Hg})\end{array}$ & $\begin{array}{c}\text { Diastolic blood } \\
\text { pressure }(\mathrm{mm} \mathrm{Hg})\end{array}$ \\
\hline \multicolumn{3}{|c|}{ Total red meat (g/24 h): } \\
\hline 1 & $1.59(0.48 \text { to } 2.69)^{\star \star \star}$ & $0.90(0.14 \text { to } 1.66)^{\star \star}$ \\
\hline 2 & $1.28(0.17 \text { to } 2.39)^{\star \star}$ & $0.76(-0.01$ to 1.52$)$ \\
\hline 3 & $1.25(0.04 \text { to } 2.45)^{\star \star}$ & $0.73(-0.10$ to 1.56$)$ \\
\hline $4 a$ & $1.23(0.02 \text { to } 2.44)^{\star \star}$ & $0.74(-0.10$ to 1.57$)$ \\
\hline $4 b$ & $1.18(-0.04$ to 2.39$)$ & $0.67(-0.17$ to 1.51$)$ \\
\hline $4 C$ & $1.21(0.01 \text { to } 2.41)^{\star \star}$ & $0.74(-0.09$ to 1.58$)$ \\
\hline $4 d$ & $1.28(0.08 \text { to } 2.49)^{\star \star}$ & $0.75(-0.08$ to 1.59$)$ \\
\hline $4 \mathrm{e}$ & $0.98(-0.25$ to 2.21$)$ & $0.59(-0.27$ to 1.44$)$ \\
\hline $4 f$ & $1.51(0.12 \text { to } 2.90)^{\star \star}$ & $0.91(-0.05$ to 1.87$)$ \\
\hline $4 g$ & $1.22(0.02 \text { to } 2.43)^{\star \star}$ & $0.73(-0.10$ to 1.57$)$ \\
\hline $4 \mathrm{~h}$ & $1.62(0.28 \text { to } 2.95)^{\star \star \star}$ & $0.93(0.01 \text { to } 1.86)^{\star \star}$ \\
\hline \multicolumn{3}{|c|}{ Beef (g/24 h): } \\
\hline 1 & $1.34(0.30 \text { to } 2.39)^{\star \star \star}$ & $0.70(-0.02$ to 1.45$)$ \\
\hline 2 & $1.13(0.09 \text { to } 2.17)^{\star \star}$ & $0.59(-0.15$ to 1.31$)$ \\
\hline 3 & $0.99(-0.10$ to 2.07$)$ & $0.50(-0.25$ to 1.26$)$ \\
\hline $4 a$ & $0.97(-0.11$ to 2.06$)$ & $0.51(-0.25$ to 1.20$)$ \\
\hline $4 b$ & $0.96(-0.13$ to 2.04$)$ & $0.51(-0.27$ to 1.24$)$ \\
\hline $4 C$ & $0.96(-0.12$ to 2.05$)$ & $0.48(-0.24$ to 1.29$)$ \\
\hline $4 d$ & $0.98(-0.10$ to 2.06$)$ & $0.51(-0.25$ to 1.26$)$ \\
\hline $4 \mathrm{e}$ & $0.78(-0.32$ to 1.88$)$ & $0.51(-0.37$ to 1.10$)$ \\
\hline $4 f$ & $1.14(-0.11$ to 2.39$)$ & $0.39(-0.25$ to 1.48$)$ \\
\hline $4 g$ & $1.01(-0.08$ to 2.09$)$ & $0.61(-0.23$ to 1.28$)$ \\
\hline $4 \mathrm{~h}$ & $1.09(-0.05$ to 2.22$)$ & $0.53(-0.58$ to 1.37$)$ \\
\hline
\end{tabular}

1=age, sex, sample, height, weight, special diet, supplement use, physical activity, cardiovascular disease and diabetes, family history of hypertension; 2=plus urinary sodium, urinary potassium, and alcohol; $3=$ plus cholesterol, saturated fatty acids, and polyunsaturated fatty acids; $4 a=$ plus fibre; $4 b=$ or plus vegetable protein; $4 c=$ or plus magnesium; $4 \mathrm{~d}=$ or plus phosphorus; $4 \mathrm{e}=$ or plus calcium; $4 \mathrm{f}=$ or plus haem iron; $4 \mathrm{~g}=$ or plus non-haem iron; $4 \mathrm{~h}=$ or plus animal protein. ** $\mathrm{P}<0.01$.

*** $\mathrm{P}<0.001$.

†2 SD difference: $102.6 \mathrm{~g} / 24 \mathrm{~h}$ (red meat) and $75.6 \mathrm{~g} / 24 \mathrm{~h}$ (beef). 


\section{WHAT IS ALREADY KNOWN ON THIS TOPIC}

Sodium intake, alcohol, and caloric imbalance have shown direct associations with blood pressure and potassium intake inverse associations

Relations between iron and blood pressure are largely unknown

\section{WHAT THIS STUDY ADDS}

Intake of total iron and non-haem iron was inversely related to blood pressure

Red meat consumption, the major food source of haem iron, was associated with higher blood pressure

\section{Conclusions}

We found an inverse association of dietary total iron intake and non-haem iron intake with blood pressure. A weak direct association between haem iron and blood pressure was observed, probably reflecting the adverse relation of red meat consumption to blood pressure. Higher red meat intake was independently associated with higher blood pressure, including after control for fatty acids, animal protein, and haem iron consumption. These findings need to be tested in other populations, clinical trials, and experimental studies.

We thank study staff at local, national, and international centres for thei efforts; a partial listing of these colleagues is given in reference 26. Contributors: IT conceived this study, analysed the data, interpreted the results, and drafted the manuscript. IJB was also involved with data analysis and helped with interpretation of results and preparation of the manuscript. JS and PE designed the study. JS, PE, HU, LVH, QC, and LZ interpreted the results and helped in the preparation and editing of the manuscript. PE is the guarantor.

Funding: This research has been supported by grant 2-R01-HL50490 from the US National Heart, Lung, and Blood Institute, National Institutes of Health, Bethesda, MD; by the Chicago Health Research Foundation; and by national agencies in China, Japan (Ministry of Education, Science, Sports and Culture, grant in aid for scientific research, No 090357003), and the United Kingdom. The sponsors had no role in the design or conduct of the study; the collection, management, analysis, or interpretation of the data; or the preparation, review, or approval of the manuscript.

Competing interests: None declared.

Ethical approval: This study was approved by the institutional review board for each participating centre.

Provenance and peer review: Not commissioned; externally peer reviewed. iron catalysed formation of reactive forms of oxygen free radicals and through altered cellular function ${ }^{40}$; therefore, self supplementation of iron should be discouraged without clinical assessment of iron status, especially for populations replete with iron, such as in the United States. ${ }^{41}$

\section{Limitations}

Limitations of this study include dietary assessments dependent on reporting by participants (subject to systematic and non-systematic errors), variation among food tables of different countries, and variability in daily dietary intake. All these factors are expected to produce underestimated relations of nutrients and food groups to blood pressure. To minimise these potential errors we used extensive quality control procedures, standardisation of food tables across countries, and repeated 24 hour dietary recalls and urine collections. Iron intakes estimated by the 24 hour recall method are unbiased compared with a study that used the weighed dietary intake method over 16 days. ${ }^{42}$ Although a degree of misclassification of nutrient intakes, based on four 24 hour recalls, is present (as with all dietary assessment methods), nondifferential misclassification would most likely reduce observed associations between iron and blood pressure (although the opposite might be true in some cases). ${ }^{4344}$ All data are cross sectional, thus long term influences of dietary factors on blood pressure may be underestimated. Causality cannot be inferred. Despite the comprehensive adjustment for confounders in our analyses, we cannot exclude the possibility of residual confounding by related dietary or other variables.
1 Wang Y, Wang $\mathrm{Q}$. The prevalence of prehypertension and hypertension among US adults according to the new joint national committee guidelines: new challenges of the old problem. Arch Intern Med 2004;164:2126-34.

2 Lawes CMM, Vander Hoorn S, Law MR, Elliot P, MacMahon S, Rodgers A. Blood pressure and the global burden of disease 2000 : part I. Estimates of blood pressure levels. J Hypertens 2006;24:413-22.

3 Prospective Studies Collaboration. Age-specific relevance of usual blood pressure to vascular mortality: a meta-analysis of individual data for one million adults in 61 prospective studies. Lancet 2002;360:1903-13.

4 Appel LJ, Brands MW, Daniels SR, Karanja N, Elmer PJ, Sacks FM. Dietary approaches to prevent and treat hypertension: a scientific statement from the American Heart Association. Hypertension 2006; $47: 296-308$

5 Elliott P, Stamler J, Nichols R, Dyer AR, Stamler R, Kesteloot $H$, et al. Intersalt revisited: further analysis of 24 hour sodium excretion and blood pressure within and across populations. $B M$ 1996;312:1249-53.

6 Sacks FM, Svetkey LP, Vollmer WM, Appel LJ, Bray GA, Harsha D, et al. Effects on blood pressure of reduced dietary sodium and the dietary approaches to stop hypertension (DASH) diet. N Engl J Med 2001;344:3-10.

7 Whelton PK, He J, Cutler JA, Brancati FL, Appel LI, Follmann D, et al. Effects of oral potassium on blood pressure: meta-analysis of randomized controlled clinical trials. JAMA 1997;277:1624-32.

8 Xin X, He J, Frontini MG, Ogden LG, Motsamai OI, Whelton PK. Effects of alcohol reduction on blood pressure. A meta-analysis of randomized controlled trials. Hypertension 2001;38:1112-7.

9 Elliott P, Stamler J, Dyer AR, Appel L, Dennis B, Kesteloot H, et al. Association between protein intake and blood pressure: the INTERMAP study. Arch Intern Med 2006;166:79-87.

10 Ueshima H, Stamler J, Elliott P, Chan Q, Brown IJ, Carnethon MR, et al. Food Omega-3 fatty acid intake of individuals (total, linolenic acid, long-chain) and their blood pressure: INTERMAP study. Hypertension 2007; 50:313-9.

11 Elliott P, Kesteloot H, Appel LJ, Dyer AR, Ueshima H, Chan Q, et al. Dietary phosphorus and blood pressure: INTERMAP study. Hypertension 2008;51:669-75.

12 Sullivan JL. Effects of dietary iron intake on stored iron, free iron, and coronary disease. Circulation 1994;90:3122-3.

13 Danesh J, Appleby P. Coronary heart disease and iron status: metaanalyses of prospective studies. Circulation 1999;99:852-4. 
14 Klipstein-Grobusch K, Grobbee DE, den Breeijen JH, Boeing H, Hofman A, Witteman JC. Dietary iron and risk of myocardial infarction in the Rotterdam study. Am J Epidemiol 1999;149:421-8.

15 Malaviarachchi D, Veugelers PJ, Yip AM, MacLean DR. Dietary iron as a risk factor for myocardial infarction. Public health considerations for Nova Scotia. Can J Public Health 2002;93:267-70.

16 Qi L, van Dam RM, Rexrode K, Hu FB. Heme iron from diet as a risk factor for coronary heart disease in women with type 2 diabetes. Diabetes Care 2007;30:101-6.

17 Reunanen A, Takkunen H, Knekt P, Seppanen R, Aromaa A. Body iron stores, dietary iron intake and coronary heart disease mortality. J Intern Med 1995;238:223-30.

18 Tavani A, Gallus S, Bosetti C, Parpinel M, Negri E, La VC. Dietary iron intake and risk of non-fatal acute myocardial infarction. Public Health Nutr 2006;9:480-4.

19 Tzonou A, Lagiou P, Trichopoulou A, Tsoutsos V, Trichopoulos D. Dietary iron and coronary heart disease risk: a study from Greece. Am Epidemiol 1998;147:161-6.

20 Van der A DL, Peeters PHM, Grobbee DE, Marx JJM, van der Schouw YT. Dietary haem iron and coronary heart disease in women. Eur Heart 2005;26:257-62.

21 Ascherio A, Willett WC, Rimm EB, Giovannucci EL, Stampfer MJ. Dietary iron intake and risk of coronary-disease among men. Circulation 1994;89:969-74.

22 Cade JE, Moreton JA, O'Hara B, Greenwood DC, Moor J, Burley VJ et al. Diet and genetic factors associated with iron status in middle-aged women. Am J Clin Nutr 2005;82:813-20.

23 Hallberg L. Advantages and disadvantages of an iron-rich diet. Eur J Clin Nutr 2002;56:S12-8.

24 De Champlain J, Wu R, Girouard H, Karas M, EL Midaoui A, Laplante MA, et al. Oxidative stress in hypertension. Clin Exp Hypertens 2004;26:593-601.

25 Savoia C, Schiffrin EL. Vascular inflammation in hypertension and diabetes: molecular mechanisms and therapeutic interventions. Clin Sci (Lond) 2007;112:375-84.

26 Stamler J, Elliott P, Dennis B, Dyer AR, Kesteloot H, Liu K, et al. INTERMAP: background, aims, design, methods, and descriptive statistics (non-dietary). J Hum Hypertens 2003;17:591-608.

27 Buzzard M. 24-Hour dietary recall and food record methods, 2nd ed. Oxford: Oxford University Press, 1998.

28 Dennis B, Stamler], Buzzard M, Conway R, Elliott P, Moag-Stahlberg A et al. INTERMAP: the dietary data-process and quality control. J Hum Hypertens 2003;17:609-22.

29 Schakel SF, Dennis BH, Wold AC, Conway R, Zhao L, Okuda N, et al. Enhancing data on nutrient composition of foods eaten by the participants in the INTERMAP study in China, Japan, the United Kingdom, and the United States. J Food Compost Anal 2003;16:395-408.

30 Monsen ER, Hallberg L, Layrisse M, Hegsted DM, Cook JD, Mertz W, et al. Estimation of available dietary iron. Am J Clin Nutr 1978;31:134-41.
31 Grandits GA, Bartsch GE, Stamler J. Chapter 4. Method issues in dietary data analysed in the multiple risk factor intervention trial. $\mathrm{Am}$ J Clin Nutr 1997;65(suppl):211S-27S.

32 Dyer AR, Shipley M, Elliott P. Urinary electrolyte excretion in 24 hours and blood pressure in the INTERSALT study. I. Estimates of reliability. The INTERSALT Cooperative Research Group. Am J Epidemiol 1994;139:927-39.

33 Hallberg L, Hulthen L. Prediction of dietary iron absorption: an algorithm for calculating absorption and bioavailability of dietary iron. Am J Clin Nutr 2000;71:1147-60.

34 Cook JD. Adaptation in iron-metabolism. Am J Clin Nutr 1990;51:301-8.

35 Rose G. Strategy of prevention: lessons from cardiovascular disease. BMJ 1981;282:1847-51.

36 Ascherio A, Hennekens C, Willett WC, Sacks F, Rosner B, Manson J, et al. Prospective study of nutritional factors, blood pressure, and hypertension among US women. Hypertension 1996;27:1065-72.

37 Miura K, Greenland P, Stamler J, Liu K, Daviglus ML, Nakagawa H. Relation of vegetable, fruit, and meat intake to 7 -year blood pressure change in middle-aged men: the Chicago Western Electric Study. Am J Epidemiol 2004;159:572-80.

38 Steffen LM, Kroenke CH, Yu X, Pereira MA, Slattery ML, Van Horn L, et al. Associations of plant food, dairy product, and meat intakes with $15-y$ incidence of elevated blood pressure in young black and white adults: the Coronary Artery Risk Development in Young Adults (CARDIA) Study. Am J Clin Nutr 2005;82:1169-77.

39 Roughead ZK, Hunt JR. Adaptation in iron absorption: iron supplementation reduces nonheme-iron but not heme-iron absorption from food. Am J Clin Nutr 2000;72:982-9.

40 Zacharski LR, Chow BK, Howes PS, Shamayeva G, Baron JA, Dalman RL, et al. Reduction of iron stores and cardiovascula outcomes in patients with peripheral arterial disease: a randomized controlled trial. JAMA 2007;297:603-10.

41 Fleming DJ, Jacques PF, Tucker KL, Massaro JM, D’Agostino RB Sr, Wilson PW, et al. Iron status of the free-living, elderly Framingham heart study cohort: an iron-replete population with a high prevalence of elevated iron stores. Am J Clin Nutr 2001;73:638-46.

42 Bingham SA, Gill C, Welch A, Day K, Cassidy A, Khaw KT, et al. Comparison of dietary assessment methods in nutritional epidemiology: weighed records $v 24 \mathrm{~h}$ recalls, food-frequency questionnaires and estimated-diet records. Brit / Nutr 1994;72:619-43.

43 Jurek AM, Greenland S, Maldonado G, Church TR. Prope interpretation of non-differential misclassification effects: expectation vs. observations. Int J Epidemiol 2005;34:680-7.

44 Liu K. Measurement error and its impact on partial correlation and multiple linear regression analyses. Am J Epidemiol 1988;127:864-74.

Accepted: 7 May 2008 